SoTEL Symposium 16-18 February 2022

\title{
Second-year student perceptions and use of technology during emergency remote teaching to connect with peers and instructors
}

\author{
Lynnae Venaruzzo \\ 1.venaruzzo@,westernsydney.edu.au \\ Western Sydney University \\ Negin Mirriahi \\ Negin.Mirriahi@unisa.edu.au \\ University of South Australia \\ Sasha Poquet \\ Sasha.Poquet@unisa.edu.au
}

Shane Dawson

shane.dawson@unisa.edu.au

Keywords: second-year, digital learning, help-seeking, emergency remote teaching

\section{Abstract}

Learning is a social experience and having meaningful connections with peers and instructors is important for student learning. The interpersonal relationships between students and their instructor can positively influence students' well-being, motivation and self-efficacy (Aguilera-Hermida, 2020; Almendingen et al., 2021; Gillis \& Krull, 2020; Kim \& Sax, 2009; Marković et al., 2021; Parpala et al., 2021; Pitsick, 2018). Creating productive interpersonal relationships with peers contributes to students' beliefs of being supported, respected, and valued, and increases the likelihood of students asking their peers for help (Mäkitalo-Siegl \& Fischer, 2011). When students feel connected to their peers they are more likely to engage with their peers in ways that support their learning and deepen their knowledge as a result (Shim et al., 2013). Interaction with instructors can also positively influence learning outcomes and student well-being (Pitsick, 2018), and instructors can be a valuable source of help and guidance (Ryan et al., 2001). However, during the COVID-19 pandemic and the shift to emergency remote teaching and learning, students' relationship with peers was significantly impacted (Motz et al., 2022) and forcing peer-to-peer interaction through mandating camera feeds on during live synchronous video classes disproportionately affected students from disadvantaged backgrounds and those experiencing anxiety or depression (Castelli \& Sarvary, 2021). As students were adapting to learn during the pandemic, they increased their reliance on their instructor and highly ranked instructor engagement as a factor that positively influenced their motivation (Nguyen, 2021). As motivation increases, so does self-efficacy, and when students feel supported, engaged, connected and valued by their peers and instructors, they are more likely to be successful students (Zepke, 2018).

This study examines students' experiences in using technology to connect with peers and their instructors during the COVID-19 pandemic when learning remotely. The research inquiry focusses on the second-year cohort as prior research has revealed that this group of learners tend to struggle with their learning (Kyndt et al., 2017; Milsom, 2015; Milsom \& Yorke, 2015; Southgate et al., 2014; Virtue et al., 2017; Webb \& Cotton, 2019) and experience higher levels of anxiety and depression compared to students in other years of university study prior to the COVID 19 pandemic (Liu et al., 2019). To examine their experience in peer-to-peer networks and their interactions with instructors for help seeking, interviews were undertaken at a large metropolitan Australian University in 2021 with 26 second-year students across different disciplines who had experienced emergency remote teaching in their first and second year of study.

The findings reveal that students resist using the discussion board in the Learning Management System because of perceptions of exposure and embarrassment in asking questions when they feel they are expected to know the answer. Students report that synchronous video classes using technology such as Zoom, increase feelings of 


\title{
SCHOLARSHIP OF TECHNOLOGY ENHANCED LEARNING
}

\author{
SoTEL Symposium 16-18 February 2022
}

isolation and they reach out to their peers via social media technology instead. Students are intentional in their choice of technology in connecting with peers, however in the absence of physical connections, there remains a gap in productive engagement with peers. The findings show that second-year students are reluctant to reach out to their instructor when technology is their only mode of interaction, and students report that they would have been more likely to ask for help during a face-to-face class.

\section{References}

Aguilera-Hermida, A. (2020). College students use and acceptance of emergency online learning due to COVID-19. International Journal of Education Research Open, 1. https://doi.org/10.1016/j.ijedro.2020.100011

Almendingen, K., Morseth, M. S., Gjølstad, E., Brevik, A., \& Tørris, C. (2021). Student's experiences with online teaching following COVID-19 lockdown: A mixed methods explorative study. PLOS ONE, 16(8), e0250378. https://doi.org/10.1371/journal.pone.0250378

Castelli, F. R., \& Sarvary, M. A. (2021). Why students do not turn on their video cameras during online classes and an equitable and inclusive plan to encourage them to do so. Ecology and Evolution, 11(8), 35653576. https://doi.org/10.1002/ece3.7123

Gillis, A., \& Krull, L. (2020). COVID-19 Remote Learning Transition in Spring 2020: Class Structures, Student Perceptions, and Inequality in College Courses. Teaching Sociology, 48(4), 283-299. https://doi.org/10.1177/0092055X20954263

Kim, Y. K., \& Sax, L. J. (2009). Student-Faculty Interaction in Research Universities: Differences by Student Gender, Race, Social Class, and First-Generation Status. Research in Higher Education: Journal of the Association for Institutional Research, 50(5). https://doi.org/10.1007/s11162-009-9127-X

Kyndt, E., Donche, V., Trigwell, K., Lindblom-Ylänne, S., Donche, V., Trigwell, K., \& Lindblom-Ylänne, S. (2017). Higher Education Transitions: Theory and Research. Routledge. https://doi.org/10.4324/9781315617367

Liu, X., Ping, S., \& Gao, W. (2019). Changes in Undergraduate Students' Psychological Well-Being as They Experience University Life. International Journal of Environmental Research and Public Health, 16(16), 2864. https://doi.org/10.3390/ijerph16162864

Mäkitalo-Siegl, K., \& Fischer, F. (2011). Stretching the limits in help-seeking research: Theoretical, methodological, and technological advances. Learning and Instruction, 21(2), 243-246. https://doi.org/10.1016/j.learninstruc.2010.07.002

Marković, M., Pavlović, D., \& Mamutović, A. (2021). Students' experiences and acceptance of emergency online learning due to COVID-19. Australasian Journal of Educational Technology, 37(5), 1-16. https://doi.org/10.14742/ajet.7138

Milsom, C. (2015, February 16). Disengaged and overwhelmed: Why do second year students underperform? The Guardian. https://www.theguardian.com/higher-education-network/2015/feb/16/disengaged-andoverwhelmed-why-do-second-year-students-underperform

Milsom, C., \& Yorke, M. (2015). Defining the second year. In Stepping up to the Second Year at University: Academic, Psychological and Social Dimensions (Vol. 2). Ringgold Inc.

Motz, B. A., Quick, J. D., \& Morrone, A. S. (2022). When Online Courses Became the Student Union: Technologies for Peer Interaction and Their Association With Improved Outcomes During COVID-19. Technology, Mind, and Behavior, 3(1: Spring 2022). https://doi.org/10.1037/tmb0000061

Nguyen, H.-T. T. (2021). Boosting Motivation to Help Students to Overcome Online Learning Barriers in Covid-19 Pandemic: A Case study. International Journal of Interactive Mobile Technologies (IJIM), 15(10), 4-20.

Parpala, A., Katajavuori, N., Haarala-Muhonen, A., \& Asikainen, H. (2021). How Did Students with Different Learning Profiles Experience 'Normal' and Online Teaching Situation during COVID-19 Spring? Social Sciences, 10(9), 337. https://doi.org/10.3390/socsci10090337

Pitsick, V. (2018). The Ohio State University’s Second-Year Transformational Experience Program-Pitstick. In New directions for higher education (Vol. 2018, pp. 97-107). https://onlinelibrary-wileycom.ezproxy.uws.edu.au/doi/full/10.1002/he.20296

Ryan, A. M., Pintrich, P. R., \& Midgley, C. (2001). Avoiding Seeking Help in the Classroom: Who and Why? Educational Psychology Review, 13(2), 93-114.

Shim, S., Kiefer, S., \& Wang, C. (2013). Help Seeking Among Peers: The Role of Goal Structure and Peer Climate. Journal of Orthoptera Research, 106. https://doi.org/10.1080/00220671.2012.692733 
Southgate, E., Douglas, H., Scevak, J., Macqueen, S., Rubin, M., \& Lindell, C. (2014). The academic outcomes of first-in-family in an Australian university: An exploratory study. International Studies in Widening Participation, 1, 31-45.

Virtue, E., Wells, G., \& Virtue, A. (2017). Supporting Sophomore Success Through a New Learning Community Model. Learning Communities Research and Practice, 5(2). https://washingtoncenter.evergreen.edu/lcrpjournal/vol5/iss $2 / 6$

Webb, O. J., \& Cotton, D. R. E. (2019). Deciphering the sophomore slump: Changes to student perceptions during the undergraduate journey. Higher Education, 77(1), 173-190. https://doi.org/10.1007/s10734018-0268-8

Won, S., Hensley, L. C., \& Wolters, C. A. (2021). Brief Research Report: Sense of Belonging and Academic Help-Seeking as Self-Regulated Learning. The Journal of Experimental Education, 89(1), 112-124. https://doi.org/10.1080/00220973.2019.1703095

Zepke, N. (2018, February 6). Learning with peers, active citizenship and student engagement in Enabling Education [Text]. Student Success. https://doi.org/10.5204/ssj.v9i1.433 